Open Access

\title{
Temporary work visas as US-Haiti development cooperation: a preliminary impact evaluation
}

\author{
Michael A. Clemens ${ }^{1,2^{*}}$ (D) and Hannah Postel ${ }^{1}$
}

\author{
*Correspondence: \\ mclemens@cgdev.org \\ ${ }^{1}$ Center for Global Development, \\ Washington, DC, USA \\ ${ }^{2}$ IZA, Bonn, Germany
}

\begin{abstract}
We report a small-sample, preliminary evaluation of the economic impact of temporary overseas work by Haitian agricultural workers. This work occurs in the USA in the context of a pilot program designed as a form of post-disaster development assistance to Haiti. We find that the effects of matching new seasonal agricultural jobs in the USA with Haitian workers differs markedly from the effects of more traditional forms of assistance to Haiti, in three ways: the economic benefits are shared roughly equally between Haiti and the USA; these benefits are very large, including raising the value of Haitian workers' labor by a multiple of 15; and the portion of the benefits accruing to Haiti is uncommonly well targeted for the direct benefit of poor Haitian households. We discuss implementation challenges faced by the program and the potential for policies of this kind to complement more traditional forms of development and humanitarian assistance.
\end{abstract}

JEL Classification: F22, O15, O22, R23

\section{Introduction}

The world's poorest workers can experience life-changing increases in income by working abroad, even for a short time. This is because working in a rich country typically increases the economic productivity of low-income workers by 300-1000\% (Clemens et al. 2016). By comparison, even highly successful aid projects to fight poverty tend to raise incomes of the poor by $10-40 \%$ (e.g., Banerjee et al. 2015b; Blattman et al. 2014) while a large number of such projects have no detectable effect on income (e.g., Banerjee et al. 2015a).

Income gains of this magnitude suggest important potential for a new form of international humanitarian and development policy: fostering temporary labor mobility (Luthria et al. 2006; Pritchett 2006). At this writing, New Zealand is the only country to experiment with building a seasonal labor mobility program explicitly as a form of development cooperation (Gibson and McKenzie 2014b; Ramasamy et al. 2008). The evaluation of that program, one of the only rigorous impact evaluations of temporary migration flows, found that its effects on the low-income South Pacific islands home to the program participants ranked "among the most effective development policies evaluated to date" (Gibson and McKenzie 2010, 2014a), as well as benefiting New Zealand's economy (Winters 2016). But in general, the economic effects of seasonal and temporary migration have been little studied (Dustmann and Görlach 2016). ${ }^{1}$ 
In this paper, we consider a pilot program to ease informational and bureaucratic barriers to temporary labor mobility between Haiti and the USA. We present new and preliminary evidence from a small-sample survey to evaluate the economic impact of temporary overseas work by Haitians under this program. We focus on three ways that temporary migration differs from more traditional development assistance: the mutual economic benefit to both countries, the size of the income gains, and the direct benefit to poor families. We establish the counterfactual by surveying households that were willing and prepared to work in the USA but barred from doing so by administrative events unrelated to their individual characteristics. Limitations of the results include the small sample size and possible questions of external validity.

We find that one worker-month of seasonal agricultural work by a male Haitian in the USA raises his current wage by approximately $1400 \%$, adds roughly US $\$ 3000$ to the economy of Haiti, and-if it represents a marginal addition to the stock of US seasonal agricultural workers-adds more than US $\$ 4000$ to the economy of the USA. Nearly all of the resources transferred to Haiti directly benefit poor Haitian families, with the average effect of doubling annual household income with 2-3 months of overseas work by one household member. This assesses the impact of migration to fill new agricultural jobs in the USA (the "treatment-on-treated" effect), not the impact of the project on all those it would wish to reach (the "intent-to-treat" effect). These results suggest unexplored potential in fostering temporary labor mobility as a policy to assist the poor-a policy alternative with much larger and more direct benefits at the margin than traditional aid, with direct economic benefits to both the rich and poor country involved.

\section{A small pilot project in Haiti}

In January 2010, a catastrophic earthquake in Haiti killed approximately 200,000-250,000 people, with economic costs exceeding US\$8 billion (Cavallo et al. 2010). In response, the Center for Global Development commissioned a study of how US policies on Haitian labor migration could contribute to the relief and reconstruction effort (Murray and Williamson 2011). This work highlighted the fact that regulations of the time made nearly all Haitians ineligible for employment-based visas to the USA, while there have long been important flows of unlawful migration from Haiti. It recommended that policymakers consider allowing small numbers of Haitians to apply for seasonal work visas, both to contribute to the post-earthquake recovery and to offer an alternative, legal channel to unlawful migration.

This led a bipartisan group of eight US members of Congress and a coalition of humanitarian non-governmental organizations to petition the Administration to exercise its discretion under law to make Haitians eligible to apply for seasonal employment visas. ${ }^{2}$ No change to statute was required; several months later, Haiti was granted eligibility (Napolitano 2012). This seasonal employment (“H-2") visa allows workers whose jobs do not require a university degree to enter the USA for up to 10 months each year to work at a single employer. ${ }^{3}$ To sponsor a worker, an employer must receive certification from the state and federal Department of Labor that recruitment for qualified US workers to fill each position was unsuccessful. The project considered here used exclusively the agricultural work visa ("H-2A").

The impact of granting Haiti access to the visa was difficult to assess. Visa recipients and their families could not be interviewed because the identities of US visa recipients are not 
made public. Moreover, the visa was little-used: between October 2012 and September 2013, only 15 Haitians received a seasonal work visa. ${ }^{4}$ US employers who had already been sponsoring the visa for workers of other nationalities were typically unfamiliar with Haiti and invested in the recruitment contacts and language skills needed to hire workers from Mexico, Jamaica, and Guatemala. Haitian workers and officials were typically unfamiliar with the program and its associated requirements of bureaucratic procedure and documentation.

Many policy advocates expressed skepticism in personal communications about the potential for the visa to benefit Haiti or the USA. The US seasonal work visa in general has been heavily criticized as exposing workers to abusive recruitment practices (e.g., Owens et al. 2014) and requiring burdensome and expensive procedures for employers (e.g., US Chamber of Commerce 2015). A common and fundamental objection cited the general goal of economic development policy as that of creating job opportunities within low-income countries-rendering overseas work at best a substitute for more traditional development policy.

To evaluate the impact of seasonal work visas on Haiti and the USA, a pilot project was created in late 2014. This project was designed to connect Haitian farmworkers with US employers certified as unable to successfully recruit US seasonal agricultural labor. It was set up jointly by Protect the People (PTP), a US-based nonprofit humanitarian relief consultancy; the Haiti office of the International Organization for Migration (IOM); and two Haitian agricultural workers' cooperatives, Sohaderk (in Kenscoff) and Feccano (in Plaine-du-Nord).

The principal activities of the project have been to identify US employers interested in Haitian labor and assist them to meet the requirements for seasonal work visa sponsors; to vet and train Haitian applicants for the visa in compliance with US and Haitian laws governing recruitment and workers' rights; and to assist Haitian workers with travel, including obtaining documents such as birth certificates and passports. The project received support from the philanthropy Good Ventures and pro-bono assistance and consulting from the Haitian Ministry of Foreign Affairs and the Center for Global Development. In December 2015, management of the project was passed entirely to PTP, Sohaderk, and Feccano.

\section{Evaluation method and survey sample}

In early 2015, the Haitian agricultural cooperatives created a list of 82 Haitian farmers as candidates for overseas work through the program, favoring established farmers with immediate family in Haiti who would be likely to return home when the visa term ended. The scale of overseas work to date has been small, constrained primarily by US policy barriers. In 2015, US employers sought to hire 62 workers through the program. Of these, 44 could not enter the USA because the federal Department of Labor determined that US workers were available to fill the jobs in question; 29 workers' visa applications at the US Embassy in Port-au-Prince were rejected without explanation (27 individuals were denied for both reasons). ${ }^{5}$ Some of these workers were reassigned to new employers; in the end, 14 workers were able to conduct agricultural work in the USA in 2015: seven in Alabama and seven in Oregon. Every worker returned to Haiti before his visa expired. Between January and September 2016, US employers sought to hire 238 workers, of which 180 were blocked by either the state or federal Department of Labor-thus, 
58 arrived to work in the USA, including eight of the original group who returned on a new contract.

These difficulties in project implementation greatly restricted the size of the sample available for an impact evaluation of overseas temporary work. But they also created an opportunity to carefully assess that impact. Many Haitian workers eligible and willing to work overseas via this program, and selected by a US employer, were not allowed to travel and take up employment. Almost all of these (44 out of 48) were barred from traveling for reasons outside of their control and unrelated to any personal characteristic of theirs. ${ }^{6}$ Workers who were allowed to travel will therefore tend to be much more similar to eligible workers who were not allowed to travel than to typical Haitians, in all aspects other than the fact that they did or did not travel. By comparing outcomes for those who traveled to eligible, willing participants who did not travel, we can therefore assess more accurately the effects of overseas work than by comparing participants who worked abroad to other, non-participant Haitians-even if those other Haitians were otherwise similar on easily observable characteristics. But the small sample size renders any result necessarily preliminary.

\subsection{Survey}

A small evaluation survey was carried out in May 2016 to assess the program's effects. The study was designed to measure comparative living conditions for individuals who worked in the USA in 2015 and those who had not yet had a chance to travel. Thirtytwo households, each with a different program candidate, were originally contacted for survey participation, based on geographic proximity and availability. Six households were unable to participate at the last moment (including two households with a member that traveled to the USA); we successfully contacted an additional four households without a member that traveled, bringing the sample size to the final 30. Twelve workers in the final sample had traveled to work in the USA in 2015. Five of these workers spent 13 weeks at an ornamental plant nursery in Alabama, earning US $\$ 10.59 / \mathrm{h}$; the other seven spent 4 weeks at apple farms in Oregon and Washington states, earning US $\$ 12.69 / \mathrm{h}$. All 12 returned to Haiti by the end of 2015. At the time of our survey in May 2016, eight of these had returned to the USA for another season. Five workers surveyed had been originally selected by a US employer but were unable to travel due to the visa and work certification denials mentioned above. The remaining 13 individuals in our sample had been selected for the candidate shortlist but had not yet traveled.

Interviews were conducted at the central offices of each agricultural cooperative, with PTP staff providing translation to and from Kreyòl. When the candidate himself was available, we spoke with him directly. If he had returned to the USA on another work contract, the nearest relative was contacted. The survey questions were designed to mirror the 2012 Post-Earthquake Living Conditions Survey, or ECVMAS (Enquête sur les Conditions de Vie des Ménages Après le Séisme, described in World Bank 2014). ${ }^{7}$ The major survey sections focused on basic household demographics, education and employment information, dwelling and asset details, estimated expenditures, and international transfers. An additional module was added to assess the impact of overseas work via the $\mathrm{H}-2 \mathrm{~A}$ program (in the case of those who traveled) or expectations for future overseas work (in the case of those who had not yet traveled). 
The basic characteristics of the survey sample are summarized in Table 1. The average household is a family of six, with two school-age children, living on a 1-ha farm that is their primary livelihood. They are quite poor, living in basic structures generally without any services such as sanitation, and spend more than half their income on food.

\subsection{Selection into the sample}

Haitian farmers became eligible for the survey sample because (1) they were members of two established agricultural cooperatives that were known to field workers at the Port-auPrince office of the International Organization for Migration, (2) they were selected by the leadership of those cooperatives to be among the initial participants in the program, and (3) their households were available to be interviewed May 23-27, 2016. This triple selection creates the potential for surveyed workers to be substantially different from typical Haitian farmers, which could affect the external validity of the evaluation results. We have less concern about selection affecting the internal validity of the impact evaluation, given that the survey sample includes 12 of the 14 households that had a member travel in 2015, and the fact that many of the eligible households whose members did not travel acquired this status due to a force majeure outside their control.

Figure 1 shows the Haitian communes where the interviewees reside. Sixteen of the sampled households belong to an agricultural cooperative in the Ouest Department, in and around Kenscoff: "Sohaderk" (Solidarité Haitienne pour le Développement Rural de Kenscoff). The other 14 belong to a cooperative in the Nord Department, in and around Plaine-du-Nord: "Feccano" (Fédération des Coopératives Cacaoyères du Nord). While Ouest has low rates of extreme poverty by Haitian standards (below 25\%), Nord has relatively high rates (above 33\%) (World Bank 2014, p. 27).

Notwithstanding the triple selection into the survey sample, the households in the survey sample have similar incomes to typical Haitian households. Figure 2 compares the distribution of income in the survey sample (from sources unrelated to US migration

Table 1 Summary statistics for households surveyed

\begin{tabular}{lllll}
\hline & Mean & std. dev. & Min. & Max. \\
\hline Household members & 5.8 & 1.5 & 3 & 9 \\
Children (age 5-18) & 2.1 & 1.6 & 0 & 6 \\
Farm area (hectares) & 1.1 & 0.81 & 0.25 & 4 \\
Rooms in house & 3.7 & 1.1 & 2 & 7 \\
Cement floor? & 0.8 & 0.41 & 0 & 1 \\
Cinderblock walls? & 0.7 & 0.47 & 0 & 1 \\
Metal roof? & 0.73 & 0.45 & 0 & 1 \\
Income/month (US\$) without project & 183 & 139 & 16 & 538 \\
Current expenditure/month (US\$) & 237 & 121 & 68 & 575 \\
$\quad$... of which food & 102 & 59 & 24 & 242 \\
$\ldots$.. of which education & 37 & 32 & 0 & 162 \\
$\ldots$.. of which transportation & 59 & 53 & 0 & 194 \\
$\ldots$. of which telephone & 18 & 13 & 3.2 & 60 \\
$\ldots$. of which household exp. & 21 & 18 & 4 & 81 \\
\hline
\end{tabular}

Includes all 30 households interviewed, whether or not the worker from that household was allowed to travel. "Without project" means without including remittances or repatriated savings by a household member that worked in the USA via this project. Income and expenditure are for the entire household, average per month over the year prior to the interview. 2016 US\$, inflated from 2012 exchange-rate $\$$ with US CPI 


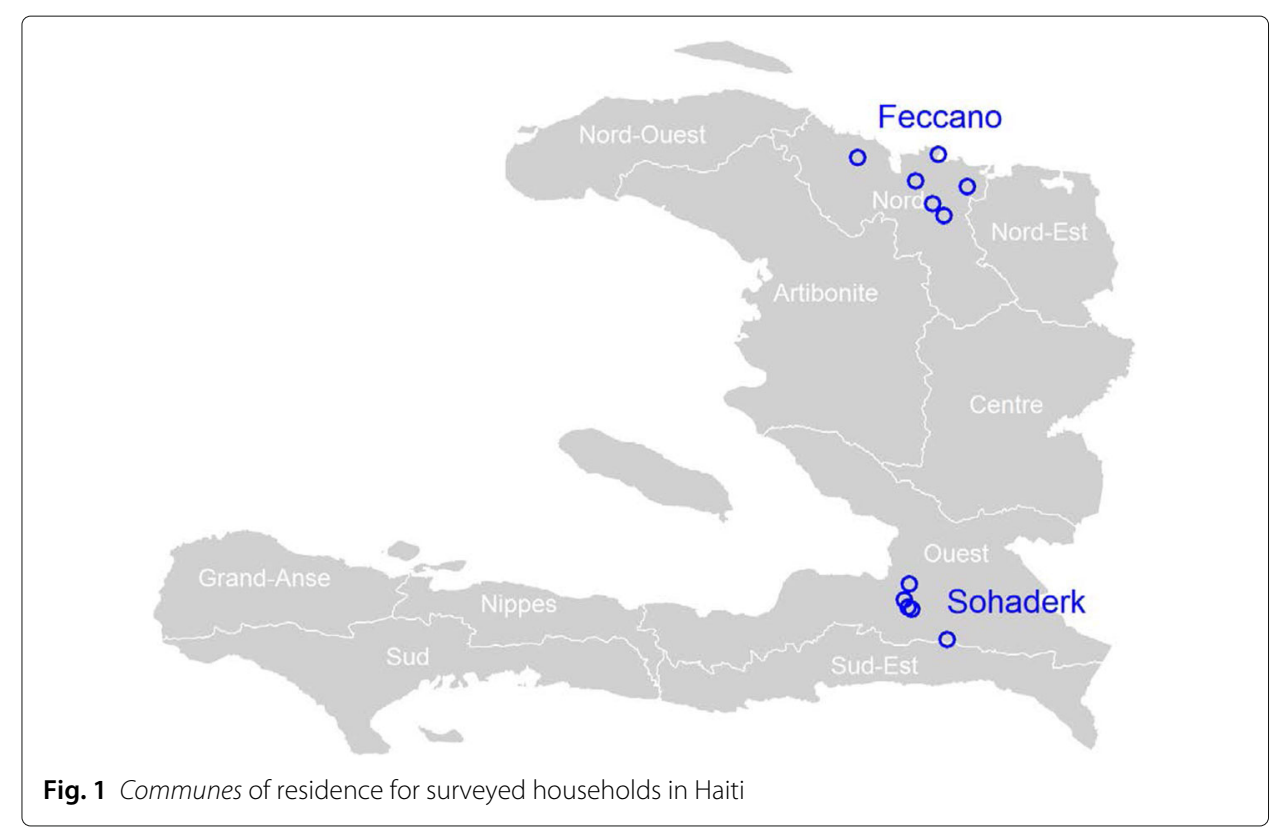

through this program) to the distribution of household incomes in a nationally representative sample. The mean monthly income of project-eligible households from non-project sources is US $\$ 206$ (95\% confidence interval $[124,288]$ ). This is statistically indistinguishable from the mean household income in the whole country, US\$250 (in 2016, dollars inflated from 2012 with the US Consumer Price Index). This limits the extent to which concerns about unobserved differences between the sample and the general population could constrain the external validity of our findings on impacts related to income.

\section{Results}

Here, we compare differences in economic outcomes in the survey sample according to whether or not a member of the household was allowed to work in the USA in 2015. The US decisions that disallowed some workers from entering the USA were largely
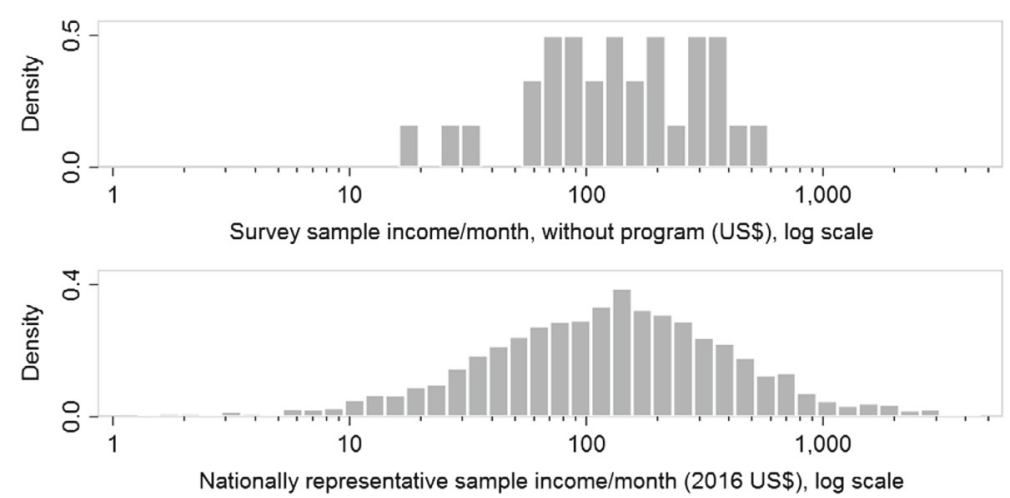

Fig. 2 Non-program income per household in survey sample versus the nation. The survey sample includes all 30 households, with incomes converted at 62 gourdes/dollar, the rate at the time of interviews in May 2016. The nationally representative sample is the 4930 households in the ECVMAS 2012, weighted by sampling weight. ECVMAS incomes are converted at 42.2 gourdes/dollar, the average for October 2012 (the middle of the ECVMAS interview period) and inflated to 2016 dollars with the US Consumer Price Index 
independent of the workers' individual characteristics. We therefore interpret economic differences between the allowed and disallowed groups as estimates of the effect of overseas work.

\subsection{Effects of overseas work on household income}

Current income. Figure 3 suggests that working in the USA had very large effects on household income. Figure 3a considers household income during any given month that workers were present in the USA. For the households with a worker in the USA, these estimates conservatively assume that the household received income from Haitian sources pro-rated downward according to the fraction of the year that the US worker was absent. This is because farms of all workers who traveled continued to operate while they were gone, though often at levels of production that decreased to a greater extent with longer absence. Thus, for example, if a household earned US\$150/month in Haiti and a member spent three months in the USA (that is, $1 / 4$ of the year) earning US $\$ 1800 /$ month, we estimate their current income per month while abroad as $\left(1-\frac{1}{4}\right) 150+1800=$ US\$1912.5. ${ }^{8}$

In the figure, each black dot of the histogram represents a single household. While workers were in the USA, income to them and their households averaged US\$2278 per month (95\% confidence interval [2137, 2420]), while income of eligible and willing families who could not travel averaged US\$147 (95\% c.i. [88, 207]). ${ }^{9}$

Average income across 1 year. Figure $3 \mathrm{~b}$ considers only income received by members of the household who remained in Haiti, as a monthly average across all 12 months of the year that preceded the survey. This average includes remittances and repatriated savings

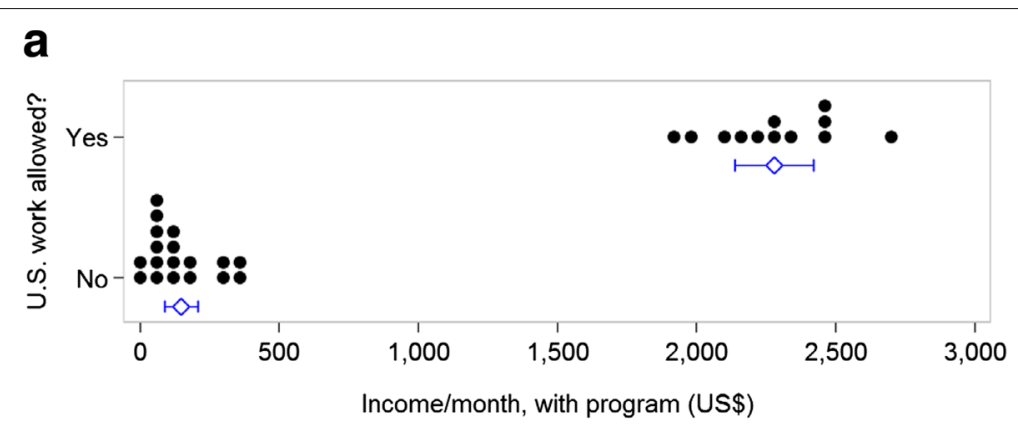

b

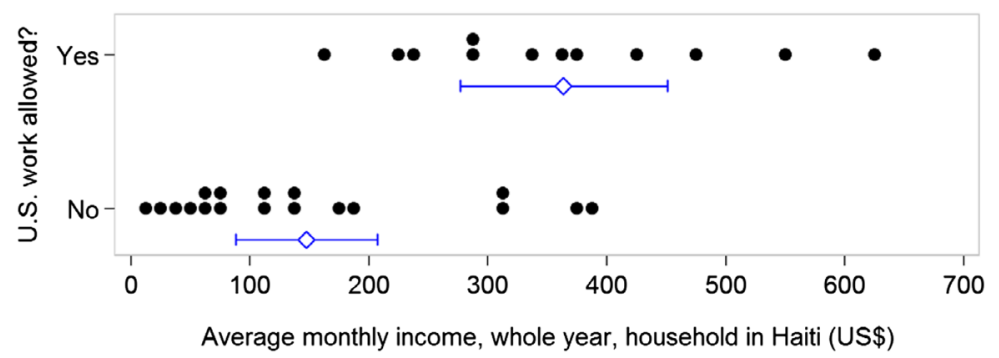

Fig. 3 Effects on income. Each black dot in histograms shows one household. Diamond shows group sample mean, surrounded by $95 \%$ confidence interval for group population mean. The exchange rate used is 62 gourdes/dollar, current at the time of the survey (May 2016). a Monthly income while workers abroad, all household members. b Average monthly income across entire year, household members in Haiti 
from the time that workers who traveled were abroad but may not include savings personally retained by the worker after return. ${ }^{10}$ It also includes several months when they were not abroad, reflecting the fact that workers only spent a small portion of the year working abroad. That is, we arrive at this monthly average income by summing 12 months of income from sources in Haiti, adding to that all money earned in the USA over the course of 2015 that was given to household members who remained in Haiti, and dividing the resulting sum by 12 .

For those in Haiti who had a household member travel to the USA, the average monthly income over the preceding year was US\$364 (95\% c.i. [277, 451]). In households without a member who traveled through the program, the average income was US\$147 (95\% c.i. $[88,207])$, as noted above. ${ }^{11}$

In the same group, if we omit from the reported income all remittances and repatriated savings via this project, the average monthly income in the group with a household member who traveled was US\$237 (95\% c.i. [140, 334]). A $t$ test of the equality of population means between non-project income in the "traveled" sample and the "did not travel" sample fails to reject equality with $p=0.081$. But we do not necessarily expect equality of non-project income between the households of those who traveled and those who did not travel because it is possible that income from temporary work overseas could have affected Haiti-based sources of income. Several of the survey respondents with a household member who traveled reported spending some of the proceeds from overseas work on things that could have affected Haiti-based household income by the time of the survey. These include agriculture inputs such as seeds and fertilizer and inventory for home-based shops.

These estimates indicate that working temporarily in the USA raised the value of project-eligible Haitian farmers' labor while abroad by approximately $1400 \%$ (a factor of 15), relative to its current value in Haiti. Even a short span of several weeks' work in the USA was sufficient to more than double annual household income received by other household members. These effects are so large that they are statistically significant even in this small sample.

\subsection{Effects on household expenditure and investment}

Figure 4 suggests that the large increase in income occasioned by working in the USA had negligible effects on the current consumption expenditures of eligible households.

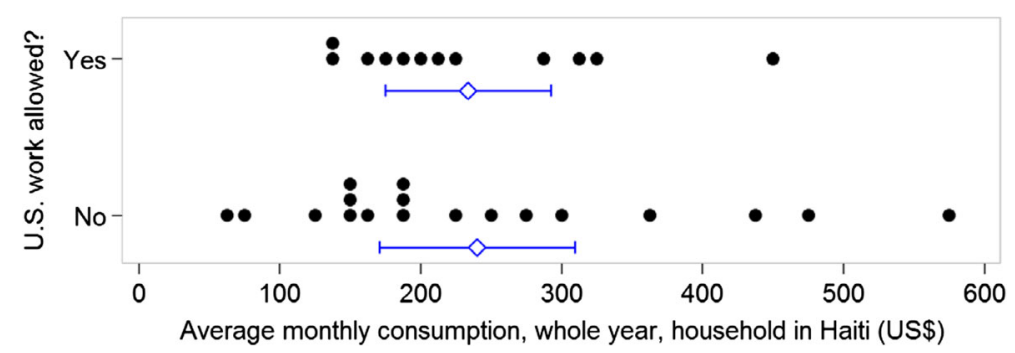

Fig. 4 Effects on current consumption expenditures. Current consumption expenditures includes: food, education, transport, communication, and other household expenses. Each black dot in histograms shows one household. Diamond shows group sample mean, surrounded by $95 \%$ confidence interval for the group population mean 
Here, "current consumption" expenditures include food, communications, transportation, education, and other recurring household expenditures. It excludes large purchases of durable goods, land, livestock, construction, agricultural tools, and shop inventory. In the "traveled" group, the average household monthly expenditures during the year prior to the survey were US\$234 (95\% c.i. $[175,292])$, and in the "did not travel" group US\$240 (95\% c.i. $[170,309])$. These are statistically indistinguishable. ${ }^{12}$ This behavior accords with economic theory and evidence from several countries that consumers typically smooth consumption over time and tend to consume little of transitory income shocks, even large ones (reviewed by Jappelli and Pistaferri 2010).

Respondents were asked about current consumption expenditures in the month prior to the interview. To capture any large expenditures that may have occurred immediately after some workers' return to Haiti-typically 5-6 months before the interview-respondents were separately asked to enumerate any major purchases they had made over the previous 8 months. These included livestock, land, construction, and tools. In the "traveled" group, the mean major expenditure over the 8-month period was US\$654 (95\% c.i. [35, 1273]), and in the "did not travel" group US\$688 (95\% c.i. [-64, 1439]). ${ }^{13}$ The "did not travel" group includes one important outlier, suggesting that a comparison of medians is more informative. In the "traveled" group, the median major expenditures over 8 months were US\$292, and in the "did not travel" group US\$153.

All "traveled" households expressed plans to dedicate earnings from abroad to durable goods and investments. At the time of the survey, seven of the 12 households with a member who traveled had already begun this: two began home construction work (Fig. 5), three bought durable goods, and four paid down outstanding debt for agricultural investments. Each household surveyed also reported using the funds remitted to support other family members in Haiti, though it was difficult to quantify the size of these transfers. As eight of the workers had already traveled again to the USA for the 2016 farming season, many household members said they would wait for the household member to return to Haiti at the end of the year to undertake the bulk of investments. Eight households had plans to expand their home, three hoped to buy more livestock, and three planned to open or expand small household shops.

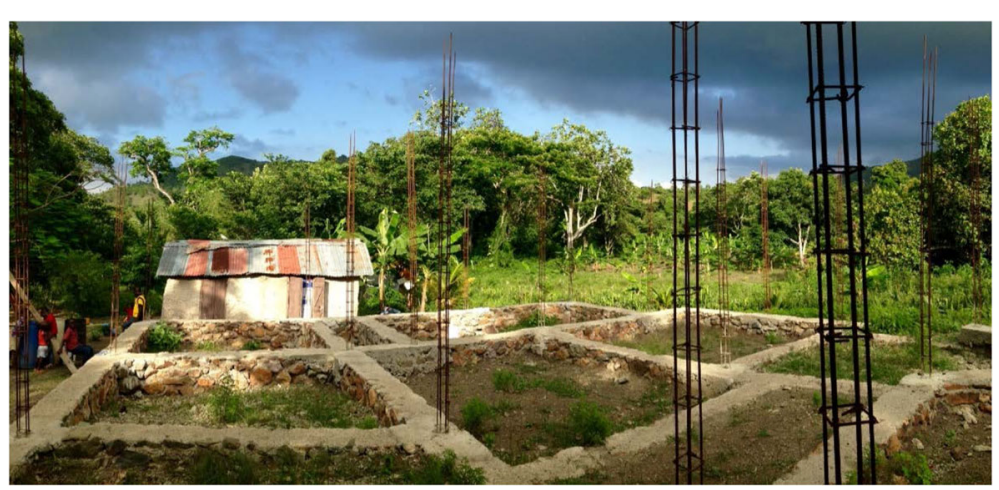

Fig. 5 New home construction in Haiti by a worker allowed to work in the USA. In the foreground is the foundation for the new home of a worker allowed to work in the USA in 2015, under construction in 2016 for his family of seven. In the background is his current two-room home. This was taken on May 22, 2016 in Milot, Nord, by Hannah Postel 
We observe no effect on overseas work on school attendance by children living in the workers' households; nearly all children age 5-18 in the households surveyed are attending school. The average fraction of children age 5-18 who are attending school is 1.0 in the households whose member worked in the USA through this program and 0.987 in the group whose member did not work in the USA. These are statistically indistinguishable in a two-sample test for equality of proportions $(p=0.74)$.

\section{Qualitative impacts}

Because prior research has shown that the objective economic impacts of migration on migrants can vary greatly from the impact on subjective well-being (Stillman et al. 2015), we asked all respondents questions related to subjective perceptions of temporary work in the USA. Every individual surveyed from a household whose member had traveledeither the worker who traveled or a close family members-expressed a desire to repeat US employment. Every household whose member had not yet traveled expressed a desire for the member to travel in the near future. Those who had already traveled to the USA universally rated their satisfaction with the program as a 10 out of 10 . Beyond the sizable economic impacts of the program described above, workers who had traveled also noted improved agricultural skills and a sense of greater freedom and empowerment. "Now I can do anything I want," a farmer's wife from the Nord department explained. The head of the agricultural cooperative Sohaderk expressed his satisfaction with the program, noting that those who had worked overseas passed on their new knowledge and skills to their neighbors upon return.

Households with workers who traveled reported substituting for the absent worker's labor either with other family members or with assistance from members of their cooperative association. None reported hiring additional help for monetary compensation due to the absence. And none of these mentioned a substantial decline in home-plot production.

Eligible and willing workers who were not allowed to work in the USA did not have unrealistically high impressions of their earning potential there. Each worker who had been unable to travel was asked what they believed they could have earned in the USA. Almost all reported a figure that was approximately correct (US\$80-100 per day), though three respondents reported a figure of US $\$ 10$ per day, a substantial underestimate of their true earning potential.

Beyond the household interviews in Haiti, the seven men who worked in Alabama were personally interviewed at the Alabama farm, each in isolation from the others and with a Kreyòl translator. Each was asked what concerns he had about the program and what he would change about it. None of the seven reported anything that he would change about the program, and the only concern-reported by several of the respondents-was their concern that the project might not continue and they would be unable to work in the USA again.

These perceptions differ markedly from descriptions of the US work under the same visa as comparable to "slavery" (e.g., SPLC 2013). This suggests that well-known abuses of other (especially Mexican) seasonal workers on the same visa, such as the charging of illegal and exorbitant recruitment fees (e.g., Owens et al. 2014) is not an inherent trait of the visa or of seasonal work itself but of contextual factors, especially unregulated recruitment. This project and its effects on participants suggest that recruitment can be properly designed to deliver very large benefits to users of the visa. 


\section{Differences with traditional aid policy}

These preliminary results from a small survey are sufficient to suggest three important differences between this project, designed to assist poor Haitians, and more traditional aid policy designed with the same goal. The available data suggest that temporary overseas work by Haitians directly benefited the economies of both the USA and Haiti, whereas traditional aid would benefit the economy of Haiti at best; that overseas work resulted in much larger financial benefits per participant than traditional aid; and that overseas work targeted and benefited poor households much more directly than traditional aid. Here, we review the evidence for each of these assessments.

\subsection{Economic effects in both Haiti and the USA}

Labor mobility by these Haitian workers is likely to have effects beyond the household level. First, it is likely to have economic multiplier effects in Haiti. The survey evidence suggests that, for every worker-month of overseas work, approximately US $\$ 1700$ will eventually be spent in Haiti. Very little of the actual or planned expenditure described by survey respondents could include imported goods, and essentially, none of it will be invested outside Haiti. This means that these expenditures ripple through the local and national economy, raising GDP by more than one dollar for each dollar spent (Djajić 2014). The economics literature contains no estimate of the size of this multiplier effect in Haiti, but the few available estimates for other developing countries range from 1.9 for poor villages in Mexico (Taylor 2004, p. 164) to 2.8 for Morocco (Glytsos 2005). A rough, reasonable estimate would therefore be that each worker-month of Haitian seasonal agricultural work in the USA contributes at least US $\$ 3000$ to Haiti's current GDP.

Second, when US farmers expand their seasonal workforce, they add value to the US economy. In this way, labor mobility differs sharply from a transfer of traditional foreign aid. The degree to which it adds value in the USA depends on the degree to which the US farmers who hire the workers could achieve the same productivity by substituting other production inputs, such as foreign workers from other countries, domestic workers, or capital. Here, we analyze the effect of an expansion in the foreign seasonal worker stock that is supplied from Haiti, not the substitution of a foreign worker from (say) Mexico with a Haitian worker. Thus, the productivity effect of a new seasonal agricultural workerfrom anywhere, but in this case from Haiti-depends on the potential to substitute that foreign labor with domestic labor or capital. The potential for substitution with domestic labor is nonzero but small: Clemens (2013a) finds that domestic labor supply to similar seasonal agricultural jobs in the state of North Carolina barely changed during the Great Recession-as local unemployment spiked from 4 to $11 \%$-implying that domestic labor supply to seasonal agricultural jobs is low and inflexible. This corroborates the state and federal Dept. of Labor assessment in the case of the positions held by Haitian workers in this project that US workers could not be recruited. But farmers could nevertheless partially substitute for manual seasonal labor by spending more on other non-labor inputs, which we explore below.

We can make rough estimates of the economic effects of this work on the US economy according to different assumptions about this substitution with other non-labor inputs. In the short run, there can be no substitution, so the marginal revenue product of an hour of Haitian labor for the US farm is simply the revenue generated by the sales of the product created with that hour of work (a Leontieff production function). In the long 
run, the farmer could adjust other inputs to partially compensate for reductions in foreign seasonal labor, so the marginal revenue product of Haitian labor for the US farm would be the Leontieff estimate multiplied by the cost share of foreign labor (with unit elasticity of substitution, a Cobb-Douglas production function). ${ }^{14}$ Internal data from the employers participating in this program show that the ratio of farm revenue per unit output to Haitian wage per unit output is 3.65 , and the share of Haitian labor in production costs is 0.301 . These figures imply that for every dollar earned in Haitian wages in the USA, between $\$ 3.65$ (short run) and $\$ 1.11$ (long run) are added to the US farms' productivity, which would then ripple through other sectors. Such multiplier effects of added farm productivity through the rest of the regional US economy are well studied and are approximately 1.5 for Oregon and 2.0 for Alabama. ${ }^{15}$ These regional multipliers imply, conservatively using the 1.11 long-run multiplier on farm productivity, that a workermonth of Haitian labor expands the US economy by more than $\$ 3720$ (Oregon) $-\$ 4140$ (Alabama). ${ }^{16}$ The short-run effects would be substantially larger.

\subsection{Magnitude of financial flows}

A second way in which this program differs sharply from more traditional types of development assistance lies in the magnitude of the economic benefit to the poor. The typical experience of Haitian temporary workers in the USA through this project, people who began with typical incomes for Haitians, was to immediately raise the current value of their labor by approximately $1400 \%$. Thus, even a brief participation in overseas work (at most 13 weeks) was sufficient to approximately double the annual incomes of the rest of the household.

These gains are much larger than the income gains produced for typical Haitians by almost all other known policy interventions to reduce poverty. Positive income effects have been rigorously measured at $38-41 \%$ for grants to start-up businesses by conflictedaffected youth in Uganda (Blattman et al. 2014, p. 730); 20-25\% for international antisweatshop activism in Indonesia (Harrison and Scorse 2010); 10-30\% for a successful project to transfer productive assets to the ultrapoor in several countries (Banerjee et al. 2015b); and statistically indistinguishable from zero for a set of six different microcredit programs around the world (Banerjee et al. 2015a).

The income gains for temporary Haitian workers in the USA are of a similar order of magnitude to the income gains for poor households from Tonga and Vanuatu in New Zealand's seasonal agricultural worker program (Gibson and McKenzie 2014a). There, the annual household income in the absence of the program is NZ\$1400 in Tonga and NZ\$2500 in Vanuatu. Members of these households who perform seasonal agricultural work in New Zealand typically earn NZ\$12,000 in a year, during less than seven months of work. This implies that a temporary work visa to New Zealand increases the current value of household labor in Tonga by a factor of more than 14 and in Vanuatu by a factor of more than eight. ${ }^{17}$

\subsection{Targeting to beneficiaries}

A third way that overseas work visas differ from traditional programs to assist the poor lies in their unusually direct targeting of beneficiaries. Easterly and Williamson (2011, Table 3) find that $29 \%$ of foreign aid is spent on agency overhead and staff salaries. Action Aid (2011, p. 43) estimates that roughly half of all official development assistance does 
not reach the poor-for reasons that include being spent in the donor country or being spent to buy donor country goods and services at inflated prices. And of the fraction of aid that does reach the poor, a substantial portion does not raise the incomes of the poor by more than one dollar for each dollar of aid (Blattman and Niehaus 2014). Income earned by Haitian seasonal workers in the USA, however, goes directly to a Haitian household. More than $85 \%$ of this amount is eventually brought or transferred to Haiti-the average fraction reported by the seven workers in Alabama-and spent in Haiti by a poor family. It is difficult to identify a program of traditional aid or international charity that targets the direct benefit of poor families with similar efficiency.

If 4000 Haitian workers per year were to perform five months of similar work in the USA - fewer than the number of Jamaican workers who currently do so each year-this would generate a financial flow of over $\$ 30$ million per year. ${ }^{18}$ Unlike a numerically equivalent flow of traditional aid, essentially, this entire amount would be spent by poor Haitian families, within Haiti, on locally produced goods and services. The aforementioned evidence on local multipliers implies that this would increase Haiti's GDP by an annual amount on the order of US\$50-70 million.

\section{Conclusions}

These evaluation results contain only preliminary evidence from a small sample in a tightly constrained pilot project. They do suggest unexplored potential in policy interventions to shape labor mobility as a form of development and antipoverty policy. The policy intervention described here acted to overcome informational and bureaucratic barriers to Haiti-US labor mobility-but did not require any changes to existing legislation in either country and was able to act in a post-disaster setting. The results imply that this project differed sharply from post-earthquake aid to Haiti in three ways.

First, these estimates suggest substantial economic benefits, in both countries, from seasonal Haitian work in the USA. We find that each worker-month raises the GDP of Haiti by approximately US $\$ 3000$ and the GDP of the USA by approximately US $\$ 4000$. The US portion of this benefit depends on the workers supplying a marginal increase in USA demand for seasonal agricultural labor-which was the case in this pilot. There were 20 worker-months of US work by Haitians through this program in 2015, and 260 workermonths in 2016, for a total of 280 worker-months across both years. A lower bound on the collective economic value-added arising from this work is US\$1.96 million, shared in roughly equal proportions between the two countries. These benefits are very large considering the scale of this small pilot: 14 workers in one year, 58 in the next, all starting out among the poorest people in the hemisphere. Traditional assistance for Haiti would not be expected to provide any large direct economic benefits to the USA.

Second, the economic benefits of overseas work to poor Haitian families exceed those of almost any other known policy to assist the poor. Temporary overseas work raised the economic value of a month of Haitian farmers' labor by $1400 \%$, so much that only several weeks of overseas work was sufficient to approximately double the average annual income of their households in Haiti. Economic effects of this magnitude, for typical beneficiaries, are essentially unknown in traditional development assistance or international charity.

Third, approximately $80-85 \%$ of workers' earnings through the project were spent in Haiti, by a poor family, for their direct benefit. This is much larger than the fraction of traditional aid or charity that goes to the direct benefit of poor families. The data above 
imply that the large majority of this money was invested-principally in new construction, agricultural land, farm tools, and shop inventory.

This program also differs sharply from the only other migration-related US policy response to the Haiti earthquake, known as Temporary Protected Status (TPS). Granted shortly after the earthquake, TPS temporarily exempted most Haitians in the USA illegally from deportation if they had not committed crimes there or presented a threat to national security - provided that they had left Haiti before the disaster, not in response to the disaster. ${ }^{19}$ This designation was based on the premise that the disaster had made life extremely difficult for people in Haiti and that a stay on deportations was "an important complement to the US government's wider disaster relief and humanitarian aide response" (DHS 2010). We note that the same reasoning would support facilitating access to new opportunities for temporary labor mobility under existing law, in response to the earthquake, in limited numbers and via channels that benefit the USA. Our evaluation suggests that this program served that end.

We underscore the preliminary nature of these findings and the need for further investigation and experimentation. Much more could be learned about the effects of overseas work on Haitian families when a larger sample is available. The potential to expand policy interventions of this kind deserves study, both within Haiti and in other settings of limited economic opportunity, including post-crisis settings. Because over 4000 Jamaican workers do similar work in the USA each year and because Haiti has three times the population of Jamaica, it is prima facie plausible that on the order of 10,000 or more Haitians annually could eventually participate in such work. Programs of this kind are already demonstrated to be financially viable at large scale. There were 346,033 admissions to the USA on seasonal work visas in fiscal year 2014, and none of these received philanthropic support; all costs are paid by US employers.

The analysis above implies that such a potential future flow, if workers stayed only three months a year, would add on the order of US\$100 million annually to the Haitian economy-and more than this to the US economy. Facilitating access to lawful channels of Haiti-US labor mobility is also likely to partially substitute for unlawful migration between the two countries (Hanson 2009). The principal constraint to such expansion appears to be demonstrating the efficacy of Haitian workers to more US employers-who are typically unfamiliar with Haiti and reluctant to experiment with unknown workers during critical planting and harvesting periods - and the bureaucratic burdens of using the seasonal work visa program, which make it broadly unpopular with employers. But the possibility of large and shared benefits presented by temporary labor mobility suggest that innovation in this area deserves development policymakers' scarce resources.

\section{Endnotes}

${ }^{1}$ Clemens (2013b) measures the income effects on Indian computer programmers from short-term work in the USA; Liebensteiner (2014) estimates the income effects of seasonal construction work by Armenians in Russia; Clemens and Tiongson (Split Decisions: Household finance when a policy discontinuity allocates overseas work, forthcoming) evaluate the effects on Filipino households from participating in a visa program for temporary employment in Korea. But empirical evidence on the economic effects of temporary work visas on development and poverty reduction remains scarce (Constant et al. 2013, p. 56). 
${ }^{2}$ Sen. Marco Rubio (R-FL), Sen. Bill Nelson (D-FL), Rep. David Rivera (RFL), Rep. Ted Deutch (D-FL), Rep. Mario Díaz-Balart (R-FL), Rep. Frederica Wilson (D-FL), Rep. Ileana Ros-Lehtinen (R-FL), and Rep. Corrine Brown (DFL). Their letter to the Secretary of Homeland Security and Secretary of State is available at http://www.cgdev.org/doc/migration/Florida\%20Delegation\%20-\%20H2\%20-\%20HFRPP\%20-\%2022DEC11.pdf. The letter from nine humanitarian nongovernmental organizations working on Haiti to the Secretary of Homeland Security and Secretary of State is available at http://www.cgdev.org/doc/migration/Haiti\%20NGOs \%20-\%20H-2\%20-\%2011DEC11.pdf.

${ }^{3}$ In fiscal year 2014, there were 240,620 admissions to the USA of foreign nonimmigrant workers with seasonal agricultural work visas ("H-2A") and 105,413 with seasonal nonagricultural work visas ("H-2B"). The agricultural seasonal work visas included 224,552 from Mexico, 4377 from Jamaica, and 1486 from Guatemala (US Dept. of Homeland Security Yearbook of Immigration Statistics 2014). The number of persons receiving the visa in any given year is smaller than the number of admissions, since some workers arrive more than once in a year (for example, once to work in spring planting and again to work in fall harvest).

${ }^{4}$ Reported in: Dept. of Homeland Security, Yearbook of Immigration Statistics 2013, Nonimmigrant Supplemental Table 2.

${ }^{5}$ As is standard practice around the world, no reasons were given for the group-based denial of visas at the embassy in Port-au-Prince. The most common reasons for denial of a nonimmigrant visa include the officers' assessment that home-country ties such as property ownership are insufficient to motivate return. In this program, applicants were vetted and trained by Sohaderk and Feccano for several months in a process designed to ensure return. As they vetted potential participants, association leaders were aware that continued participation in the program would be jeopardized if a substantial number of workers overstayed their visas. In the event, all of the workers who traveled returned as scheduled.

${ }^{6}$ That is, 44 of the workers were unable to travel because their potential employers did not receive certification to hire them, a bureaucratic process that does not involve consideration of the workers as individuals. The group that was denied visas at the US Embassy in Port-au-Prince, which as mentioned above largely overlapped with those whose positions were not certified, was denied collectively-with no concerns noted by consular officers about particular individuals in that group.

${ }^{7}$ The ECVMAS interviews were conducted between August and December 2012. In October 2012, one US dollar averaged 42.2 gourdes.

${ }^{8}$ In one household whose member was allowed to work in the USA, the same worker while in Haiti did half-time hired construction work, and the survey respondent (his spouse) did not know how much he earned in that occupation. We impute the value of that income source using the average value of half-time construction wage earnings among ECVMAS households, in 2016 dollars: US\$118 per month.

${ }^{9}$ This is close to a purchasing power parity-adjusted estimate of the earnings differences because the vast majority of the earnings in both groups are spent in Haiti. The seven workers in Alabama, interviewed in person at their worksite, estimated that $10-15 \%$ of their US earnings were spent in the USA; the US seasonal work visa requires employers to pay for housing, transportation to and from the USA, and weekday meals, minimizing 
workers' expenses while abroad. The median in the "traveled" group is US\$2292, and in the "did not travel" group US\$108.

${ }^{10}$ Workers who traveled abroad and their families were asked how much money the worker brought/sent back to Haiti.

${ }^{11} \mathrm{~A} t$ test for the equality of population means rejects the null of equality with $p<$ 0.0001 . The median in the "traveled" group is US\$354, and in the "did not travel" group US\$108.

${ }^{12} \mathrm{~A} t$ test fails to reject equality of means with $p=0.89$. The median in the "traveled" group is US $\$ 208$, and in the "did not travel" group US\$186.

${ }^{13} \mathrm{~A} t$ test fails to reject equality of means with $p=0.95$.

${ }^{14}$ This method is discussed further in Clemens (2013a). In Cobb-Douglas production, the output elasticity of an input is well approximated by its cost share. The simplest version of the dual problem proceeds as $\min _{K, L}(w L+r K)$ s.t. $A K^{1-\alpha} L^{\alpha}=\bar{Q} \underset{\text { FoC }}{\stackrel{\alpha}{\longrightarrow}}=$ $\frac{w L}{w L+r K}$, where $K, L$ are the capital and labor, with prices $r, w$, respectively; $A$ is the total factor productivity; and $\bar{Q}$ is some output quantity. For this reason the industrial organization literature commonly approximates firm-level output elasticity with industry-level cost share of the input (e.g., Foster et al. 2008; Griliches 1963; Syverson 2004).

${ }^{15}$ These are the 2010 US Bureau of Economic Analysis Regional Input-Output Modeling System (RIMS II) regional economic model agriculture-sector multipliers for Alabama and Oregon for output across all sectors of the state economies. These are the "type I" multipliers, which omit any local spending of wages by the Haitian workers.

${ }^{16}$ For Alabama, a worker-month of Haitian labor is paid US $\$ 10.59 / \mathrm{h} \times \sim 5.5$ days/week $\times 8 \mathrm{~h} /$ day $\times 4$ weeks $/$ month $=\$ 1864$, thus, $\$ 1864 \times(1.11 \times 2.0)=\$ 4138$. For Oregon, a worker-month of Haitian labor is paid US\$12.69/h $\times \sim 5.5$ days/week $\times 8 \mathrm{~h} /$ day $\times$ 4 weeks $/$ month $=\$ 2233$, thus $\$ 2233 \times(1.11 \times 1.5)=\$ 3719$. These estimates are furthermore conservative because, by using the Cobb-Douglas estimate of the farm productivity multiplier (1.11), they assume that manual labor could be fully substituted with sufficient investment in machinery. But machinery to fully automate the tasks performed by these workers does not exist. A more reasonable but still conservative estimate would take the ratio of marginal revenue product to wage as something greater than 2.0 rather than 1.11, resulting in an estimate of over $\$ 6700-7455$ per Haitian worker-month of added value to all sectors of the US economy. The estimates are moreover conservative because they ignore multiplier effects in the USA from the $10-15 \%$ of Haitian workers' earnings that are spent in the USA.

${ }^{17}$ For example, for Tonga: NZ\$12,000/7 months = NZ\$1714/month; NZ\$1400/12 = NZ $\$ / 117 /$ month; and $1714 / 117=14.7$. This is a lower bound because not all Tongan workers stay the full duration of the maximum 7 months.

$18 \sim$ US $\$ 1700$ per worker-month $\times 5$ months $\times 4000$ workers $=$ US $\$ 34$ million.

${ }^{19}$ The announcement (DHS 2010) was accompanied by a warning that "attempting to leave Haiti now will only bring more hardship to the Haitian people and nation. ... Those who attempt to travel to the United States after January 12, 2010 will not be eligible for TPS and will be repatriated." (Napolitano 2010). This policy was revised a year and a half later, after it was clear that Haitians were not departing in large numbers, to include people who had departed after the earthquake (DHS 2011). 


\section{Acknowledgments}

We are grateful to the Protect the People and the International Organization for Migration. Sarah Williamson and Royce Murray made this work possible, and we received fieldwork assistance from Elsie Balu, Sabine Deristin, Nabil Hashmi, and Monise Jean. We are grateful to the workers and their families who participated in the survey and to Paul Altidor, Alexander Berger, Francis Cissna, Facundo Cuevas, Luca Dall'Oglio, Joel Danies, William Exantus, Frank Gasperini, Mike Gempler, Thamar Harrigan, Jon Hegeman, Jean-Robert Joseph, Federica Marzo, Tobi Metzner, Antonio Philantrope, Cynthia Rathinasamy, Drazan Rozić, William Savedoff, Marla Spivack, William L. Swing, and two anonymous reviewers. Responsible editor: Jackline Wahba.

\section{Funding}

This research was supported by a generous grant from Good Ventures.

\section{Availability of data and materials}

The data and code to replicate the figures and table in this paper are available in Harvard University's Dataverse repository, at http://dx.doi.org/10.7910/DVN/J6P2KT.

\section{Competing interests}

The IZA Journal of Labor \& Development is committed to the IZA Guiding Principles of Research Integrity. The authors declares that they have observed these principles.

\section{Disclaimer}

The paper represents the views of the authors alone and not necessarily those of the Center for Global Development, IZA, their boards, or their funders.

Received: 6 October 2016 Accepted: 21 December 2016

Published online: 27 February 2017

\section{References}

Aid Action (2011) Real aid: ending aid dependency. ActionAid, UK, London

Banerjee A, Karlan D, Zinman J (2015a) Six randomized evaluations of microcredit: introduction and further steps. Am Econ J Appl Econ 7(1):1-21

Banerjee A, Karlan D, Zinman J, Duflo E, Goldberg N, Karlan D, Osei R, Parienté W, Shapiro J, Thuysbaert B, Udry C (2015b) A multifaceted program causes lasting progress for the very poor: evidence from six countries. Science 1260799(6236)

Blattman C, Niehaus P (2014) Show them the money: why giving cash helps alleviate poverty. Foreign Aff 93(3):117-126

Blattman C, Niehaus P, Fiala N, Martinez S (2014) Generating skilled self-employment in developing countries: experimental evidence from Uganda. Q J Econ 129(2):697-752

Cavallo E, Powell A, Becerra O (2010) Estimating the direct economic damages of the earthquake in Haiti. Econ J 120(546):F298-F312

Clemens MA (2013a) The effect of foreign labor on native employment: a job-specific approach and application to North Carolina farms. Center for Global Development, Washington. CGD Working Paper 326

Clemens, MA (2013b) Why do programmers earn more in Houston than Hyderabad? Evidence from randomized processing of US visas. Am Econ Rev Pap Proc 103(3):198-202

Clemens MA, Montenegro C, Pritchett L (2016) Bounding the price equivalent of migration barriers. IZA Institute for the Study of Labor, Bonn. IZA Discussion Paper 9789

Constant AF, Nottmeyer O, Zimmermann KF (2013) The economics of circular migration(Constant AF, Zimmermann $\mathrm{KF}$, eds.). Edward Elgar Publishing, Cheltenham

DHS (2010) Designation of Haiti for temporary protected status. Fed Regist 75:3476-3479

DHS (2011) Extension and redesignation of Haiti for temporary protected status. Fed Regist 76:29000-29004

Djajić S (2014) Temporary emigration and welfare: the case of low-skilled labor. Int Econ Rev 55(2):551-574

Dustmann C, Görlach J-S (2016) The economics of temporary migrations. J Econ Lit 54(1):98-136

Easterly W, Williamson CR (2011) Rhetoric versus reality: the best and worst of aid agency practices. World Dev 39(11):1930-1949

Foster L, Haltiwanger J, Syverson C (2008) Reallocation, firm turnover, and efficiency: selection on productivity or profitability Am Econ Rev 98(1):394-425

Gibson J, McKenzie D (2010) The development impact of a best practice seasonal worker policy. World Bank, Washington. World Bank Policy Research Working Paper WPS5488

Gibson, J, McKenzie D (2014a) The development impact of a best practice seasonal worker policy. Rev Econ Stat 96(2):229-243

Gibson J, McKenzie D (2014b) Development through seasonal worker programs: the case of New Zealand's RSE program(Lucas REB, ed.). Edward Elgar Publishing, Cheltenham

Glytsos NP (2005) The contribution of remittances to growth: a dynamic approach and empirical analysis. J Econ Stud 32(6):468-496

Griliches Z (1963) Estimates of the aggregate agricultural production function from cross-sectional data. J Farm Econ 45(2):419-428

Hanson GH (2009) The economics and policy of illegal immigration in the United States. Migration Policy Institute, Washington

Harrison A, Scorse J (2010) Multinationals and anti-sweatshop activism. Am Econ Rev 100(1):247-73

Jappelli T, Pistaferri L (2010) The consumption response to income changes. Ann Rev Econ 2(1):479-506

Liebensteiner M (2014) Estimating the income gain of seasonal labor migration. Rev Dev Econ 18(4):667-680

Luthria M, Duncan R, Brown R, Mares P, Maclellan N (2006) Pacific Islands at home and away: expanding job opportunities for Pacific islanders through labor mobility. World Bank, Washington 
Murray RB, Williamson SP (2011) Migration as a tool for disaster recovery: a case study on US policy options for post-earthquake Haiti. Center for Global Development, Washington. CGD Working Paper:255

Napolitano, J (2010) Statement from Homeland Security Secretary Janet Napolitano on Temporary Protected Status (TPS) for Haitian nationals. U.S. Dept. of Homeland Security Press Release. https://www.dhs.gov/news/2010/01/15/ secretary-napolitano-temporary-protected-status-tps-haitian-nationals

Napolitano J (2012) Identification of foreign countries whose nationals are eligible to participate in the $\mathrm{H}-2 \mathrm{~A}$ and $\mathrm{H}-2 \mathrm{~B}$ nonimmigrant worker programs. Fed Regist 77(Docket No. DHS-2011-0108):2558-2559

Owens C, Dank M, Breaux J, Bañuelos I, Farrell A, Pfeffer R, Bright K, Heitsmith R, McDevitt J (2014) Understanding the organization, operation, and victimization process of labor trafficking in the United States. Washington, DC: Urban Institute Justice Policy Center and Boston, MA: Northeastern University. http://www.urban.org/research/publication/ understanding-organization-operation-and-victimization-process-labor-trafficking-united-states

Pritchett L (2006) Let their people come: breaking the gridlock on global labor mobility. Center for Global Development, Washington

Ramasamy S, Krishnan V, Bedford R, Bedford C (2008) The recognised seasonal employer policy: seeking the elusive triple wins for development through international migration. Pac Econ Bull 23(3):171-186

SPLC (2013) Close to slavery: guestworker programs in the United States. Souther Poverty Law Center, Montgomery

Stillman S, Gibson J, McKenzie D, Rohorua H (2015) Miserable migrants? Natural experiment evidence on international migration and objective and subjective well-being. World Dev 65:79-93

Syverson C (2004) Market structure and productivity: a concrete example. J Polit Econ 112(6):1181-1222

Taylor JE (2004) Remittances, savings, and development in migrant-sending areas(Massey DS, Taylor JE, eds.). Oxford University Press, Oxford

U.S. Chamber of Commerce Testimony of Randel K. Johnson (2015) Hearing before the U.S Senate Committee on Homeland Security and Governmental Affairs, 'Securing the border: defining the current population living in the shadows and addressing future flows', March 26, SD-342, Dirksen Senate Office Building. http://www.hsgac.senate. gov/hearings/securing-the-border-defining-the-current-population-living-in-the-shadows-and-addressing-futureflows

Winters LA (2016) New Zealand's recognised seasonal employer scheme: an object lesson in policy making —but for whom? Working Paper 34, Migrating Out of Poverty Research Programme. University of Sussex, Dept. of Economics. http://migratingoutofpoverty.dfid.gov.uk/files/file.php?name=wp34-winters-2016-new-zealands-recognisedseasonal-employer-scheme.pdf\&site $=354$

World Bank (2014) Investing in people to fight poverty in Haiti: reflections for evidence-based-policy making. ONPES, Washington

\section{Submit your manuscript to a SpringerOpen ${ }^{\circ}$ journal and benefit from:}

- Convenient online submission

- Rigorous peer review

- Immediate publication on acceptance

- Open access: articles freely available online

- High visibility within the field

- Retaining the copyright to your article

Submit your next manuscript at $\gg$ springeropen.com 